\title{
Glyphosate-Resistant Palmer Amaranth (Amaranthus palmeri) in Nebraska: Confirmation, EPSPS Gene Amplification, and Response to POST Corn and Soybean Herbicides
}

\author{
Parminder S. Chahal, Vijay K. Varanasi, Mithila Jugulam, and Amit J. Jhala*
}

Palmer amaranth is the most problematic weed in agronomic crop production fields in the United States. A Palmer amaranth biotype was not controlled with sequential applications of glyphosate in glyphosateresistant (GR) soybean production field in south-central Nebraska. The seeds of the putative GR Palmer amaranth biotype were collected in the fall of 2015. The objectives of this study were to (1) confirm GR Palmer amaranth and determine the level of resistance in a whole-plant dose-response bioassay, (2) determine the copy number of 5-enolpyruvylshikimate-3-phosphate (EPSPS) gene, the molecular target of glyphosate, and (3) evaluate the response of GR Palmer amaranth biotype to POST corn and soybean herbicides with different modes-of-action. Based on the effective dose required to control $90 \%$ of plants $\left(\mathrm{ED}_{90}\right)$, the putative GR Palmer amaranth biotype was 37- to 40-fold resistant to glyphosate depending on the glyphosate-susceptible (GS) used as a baseline population. EPSPS gene amplification was present in the GR Palmer amaranth biotype with up to 32 to 105 EPSPS copies compared to the known GS biotypes. Response of GR Palmer amaranth to POST corn and soybean herbicides suggest reduced sensitivity to atrazine, hydroxyphenylpyruvate dioxygenase (HPPD)- (mesotrione, tembotrione, and topramezone), acetolactate synthase (ALS)- (halosulfuron-methyl), and protoporphyrinogen oxidase (PPO)- (carfentrazone and lactofen) inhibitors. GR Palmer amaranth was effectively controlled (>90\%) with glufosinate applied at $593 \mathrm{~g}$ ai ha ${ }^{-1}$ with $\geq 95 \%$ reduction in biomass. More research is needed to determine whether this biotype exhibits multiple resistant to other group of herbicides and evaluate herbicide programs for effective management in corn and soybean.

Nomenclature: 2,4-D; acetochlor; acifluorfen; atrazine; bentazon; bromoxynil; carfentrazone; chlorimuron; dicamba; fluthiacet; fomesafen; glufosinate; glyphosate; halosulfuron; imazamox; imazethapyr; lactofen; mesotrione; S-metolachlor; tembotrione; thiencarbazone; thifensulfuron; topramezone; Palmer amaranth, Amaranthus palmeri S. Wats.; corn, Zea mays L.; soybean, Glycine max (L.) Merr.

Key words: EPSPS gene copy number, glyphosate-susceptible, herbicide efficacy, resistance confirmation, resistance management.

\begin{abstract}
Amaranthus palmeri es la malezas más problemática en campos de producción de cultivos agronómicos en los Estados Unidos. Un biotipo de $A$. palmeri no fue controlado con aplicaciones secuenciales de glyphosate en un campo de producción de soja resistente a glyphosate (GR) en el sur central de Nebraska. Las semillas del biotipo putativo GR de $A$. palmeri fueron colectadas en el otoño de 2015. Los objetivos de este estudio fueron (1) confirmar que A. palmeri es GR y determinar el nivel de resistencia en un bioensayo de respuesta a dosis con plantas completas, (2) determinar el número de copias del gen 5-enolpyruvylshikimate-3-phosphate synthase (EPSPS), el objetivo molecular de glyphosate, y (3) evaluar la respuesta del biotipo GR de $A$. palmeri a herbicidas POST para maíz y soja con diferentes modos de acción. Con base en la dosis efectiva requerida para controlar $90 \%$ de las plantas $\left(\mathrm{ED}_{90}\right)$, el biotipo putativo GR de $A$. palmeri fue 37 a 40 veces más resistente a glyphosate dependiendo de la población susceptible a glyphosate (GS) base utilizada. La amplificación del gen EPSPS estuvo presente en el biotipo GR de A. palmeri con 32 y hasta 105 copias más de EPSPS comparado con biotipos GS conocidos. La respuesta de $A$. palmeri GR a herbicidas POST para maíz y soja sugiere una sensibilidad reducida a atrazine, y a inhibidores de hydroxy phenylpyruvate dioxygenase (HPPD) (mesotrione, tembotrione, y topramezone), de acetolactate synthase (ALS) (halosulfuron-methyl), y de protoporphyrinogen oxidase (PPO) (carfentrazone y lactofen). A. palmeri GR fue efectivamente controlado (>90\%) con glufosinate aplicado a $593 \mathrm{~g}^{\text {ai }} \mathrm{ha}^{-1}$ con $\geq 95 \%$ de reducción en la biomasa. Se necesita más investigación para determinar si este biotipo exhibe resistencia múltiple a herbicidas de otros grupos y para evaluar programas de herbicidas para su manejo efectivo en maíz y soja.
\end{abstract}

\footnotetext{
DOI: $10.1614 /$ WT-D-16-00109.1

*First and fourth authors: Graduate Research Assistant and Assistant Professor (ORCID: 0000-0001-8599-4996), Department of Agronomy and Horticulture, University of Nebraska, Lincoln, NE 68583-0915; Second and third authors: Research Associate and Associate Professor, Department of Agronomy, Kansas State University, Manhattan, KS 66506. Corresponding author’s E-mail: Amit.Jhala@unl.edu
} 
Palmer amaranth is a summer annual broadleaf weed belonging to the family Amaranthaceae (Sauer 1957; Steckel 2007). Though it is native to the southwestern United States, human activities in the 20th century-including seed and equipment transportation and agriculture expansion-have led Palmer amaranth to spread to the northern United States (Culpepper et al. 2010). Palmer amaranth is a dioecious species, with pollination occurring by wind (Franssen et al. 2001). It is a prolific seed producer even under competition with agronomic crops (Burke et al. 2007; Massinga et al. 2001). A single female plant, if not controlled, can produce as many as 600,000 seeds (Keeley et al. 1987). Palmer amaranth has the greatest plant dry weight, leaf area, height, growth rate $(0.10$ to $0.21 \mathrm{~cm}$ per growing degree day), and water-use efficiency of all the pigweeds, including Amaranthus rudis Sauer, Amaranthus retroflexus L., and Amaranthus albus L. (Horak and Longhin 2000). Palmer amaranth's aggressive growth habit and prolific seed production make it a pervasive weed in agronomic crop production fields (Bensch et al. 2003; Liphadzi and Dille 2006; Massinga et al. 2001; Smith et al. 2000). A recent survey conducted by the Weed Science Society of America found that Palmer amaranth was the most problematic agricultural weed in the United States (WSSA 2016).

The continuous and sole reliance on single modeof-action herbicide programs has resulted in the evolution of herbicide-resistant weeds (Beckie 2011; VanGessel 2001). Palmer amaranth biotypes resistant to microtubule-inhibiting herbicides were reported first, followed by biotypes resistant to acetolactate synthase (ALS)-, photosystem II (PSII)-, 5-enolpyruvylshikimate-3-phosphate synthase (EPSPS)-, hydroxyphenylpyruvate dioxygenase (HPPD)-, and protoporphyrinogen oxidase (PPO)-inhibiting herbicides (Heap 2016a). In addition, Palmer amaranth resistant to multiple herbicides (e.g., ALS-, EPSPS-, HPPD-, and PSII-inhibitors) has been reported in a few states (Heap 2016a). In Nebraska, a Palmer amaranth biotype resistant to HPPD- and PSIIinhibitors has been reported (Jhala et al. 2014).

Glyphosate, a systemic and broad-spectrum herbicide, is the most widely used agricultural pesticide globally due to the widespread adoption of glyphosate-resistant (GR) crops and minimum or no-tillage practices that rely primarily on herbicides for weed control (Woodburn 2000). Since the commercialization of GR crops, glyphosate has been extensively used for POST weed control in GR corn and soybean fields in the Midwest. The estimated total glyphosate use in the United States was 18 million $\mathrm{kg}$ active ingredient per year in 1996, but rose to 125 million $\mathrm{kg}$ in 2013, a 594\% increase (USGS 2016). Glyphosate inhibits the EPSPS enzyme, a component of the shikimate pathway. Glyphosate thus prevents the biosynthesis of the aromatic amino acids phenylalanine, tyrosine, and tryptophan, resulting in the death of glyphosate-sensitive plants due to the accumulation of shikimate (Herrmann and Weaver 1999; Steinrücken and Amrhein 1980). Rigid ryegrass (Lolium rigidum Gaudin) in Australia in 1996 was the first confirmed GR weed (Powles et al. 1998), and GR Palmer amaranth was first documented in Georgia in 2004 (Culpepper et al. 2006). Since then, Palmer amaranth populations resistant to glyphosate have been documented in 25 other states in the United States (Heap 2016a).

Mechanisms of glyphosate resistance have been studied in several weed species (Dinelli et al. 2008; Perez-Jones et al. 2007; Simarmata and Penner 2008; Wiersma et al. 2015). Glyphosate resistance has been conferred by a) target site mutation in the EPSPS gene, making it insensitive to the target protein (Kaundun et al. 2011; Perez-Jones et al. 2007; $\mathrm{Yu}$ et al. 2007), b) reduced absorption and translocation of glyphosate (Dinelli et al. 2008; Yu et al. 2007; Wakelin et al. 2004), c) increased glyphosate sequestration (Ge et al. 2010), and d) EPSPS gene amplification (Chandi et al. 2012; Gaines et al. 2010; Jugulam et al. 2014; Whitaker et al. 2013). The presence of EPSPS gene copies (>100 copies) distributed throughout the genome has been confirmed in a GR Palmer amaranth biotype from Georgia (Gaines et al. 2010). Additionally, EPSPS gene amplification has been reported in Palmer amaranth populations from North Carolina (Chandi et al. 2012; Whitaker et al. 2013), Mississippi (Ribeiro et al. 2014), and New Mexico (Mohseni-Moghadam et al. 2013a). Low levels of resistance to glyphosate due to reduced uptake and translocation have also reported in Palmer amaranth biotypes from Tennessee (Steckel et al. 2008) and Mississippi (Nandula et al. 2012).

In numerous instances, persistent reliance on glyphosate for broad-spectrum and economical weed control has resulted in the evolution of GR weeds. Failure to control Palmer amaranth following sequential glyphosate applications was observed in a grower's field in Thayer County in south-central Nebraska. 
The field was under GR corn-soybean rotation with reliance on glyphosate for weed control in a no-till production system, justifying the need to evaluate the level of resistance and the mechanism involved to confer resistance. It was also deemed important to determine whether the Palmer amaranth biotype had reduced sensitivity to herbicides with other modes of action that can be used in corn and soybean. This information can be used to develop herbicide programs for the management of resistant Palmer amaranth. The objectives of this study were 1) to confirm the presence of GR Palmer amaranth in south-central Nebraska by quantifying the level of resistance in a whole-plant dose-response bioassay, 2) to compare the EPSPS gene copy number of GR Palmer amaranth with that of the susceptible biotype, and 3) to evaluate the response of GR Palmer amaranth to POST herbicides that can be used in corn and soybean.

\section{Materials and Methods}

Plant Materials. In October 2015, Palmer amaranth plants that survived sequential glyphosate applications were collected from a grower's field in Thayer County, Nebraska $\left(40.30^{\circ} \mathrm{N}, 97.67^{\circ} \mathrm{E}\right)$ (Figure 1) to serve as the putative GR biotype in this study. Palmer amaranth seed heads were collected from fields in Buffalo and Fillmore Counties in Nebraska (Figure 1); both fields have a known history of effective control with the recommended rate of glyphosate. These were considered the glyphosate-susceptible (GS) biotypes in this study, and named susceptible $1 \quad\left(S_{1}\right)$ and susceptible $2\left(\mathrm{~S}_{2}\right)$. The seeds were cleaned thoroughly using a seed cleaner and stored separately in airtight polyethylene bags at $5 \mathrm{C}$ until used in this study. Seeds were planted in square plastic pots $(10 \times 10 \times 12 \mathrm{~cm})$ containing a 2:2:2:4 (by vol) soil: sand:vermiculite:peat moss mixture. Palmer amaranth plants were thinned to one plant per pot at $10 \mathrm{~d}$ after emergence. The plants were supplied with water and nutrients and kept in a greenhouse maintained at a 30/27 C day/night temperature regime with a 16-h photoperiod supplemented by overhead sodium halide lamps.

Whole-Plant Dose-Response Bioassay. Greenhouse whole-plant dose-response bioassays were conducted in 2016 at the University of Nebraska-Lincoln to determine the level of resistance in the putative GR Palmer amaranth biotype. The two GS biotypes were included for comparison. The study was laid out in a 10 by 3 factorial experiment in a randomized complete block design with four replications. Ten glyphosate

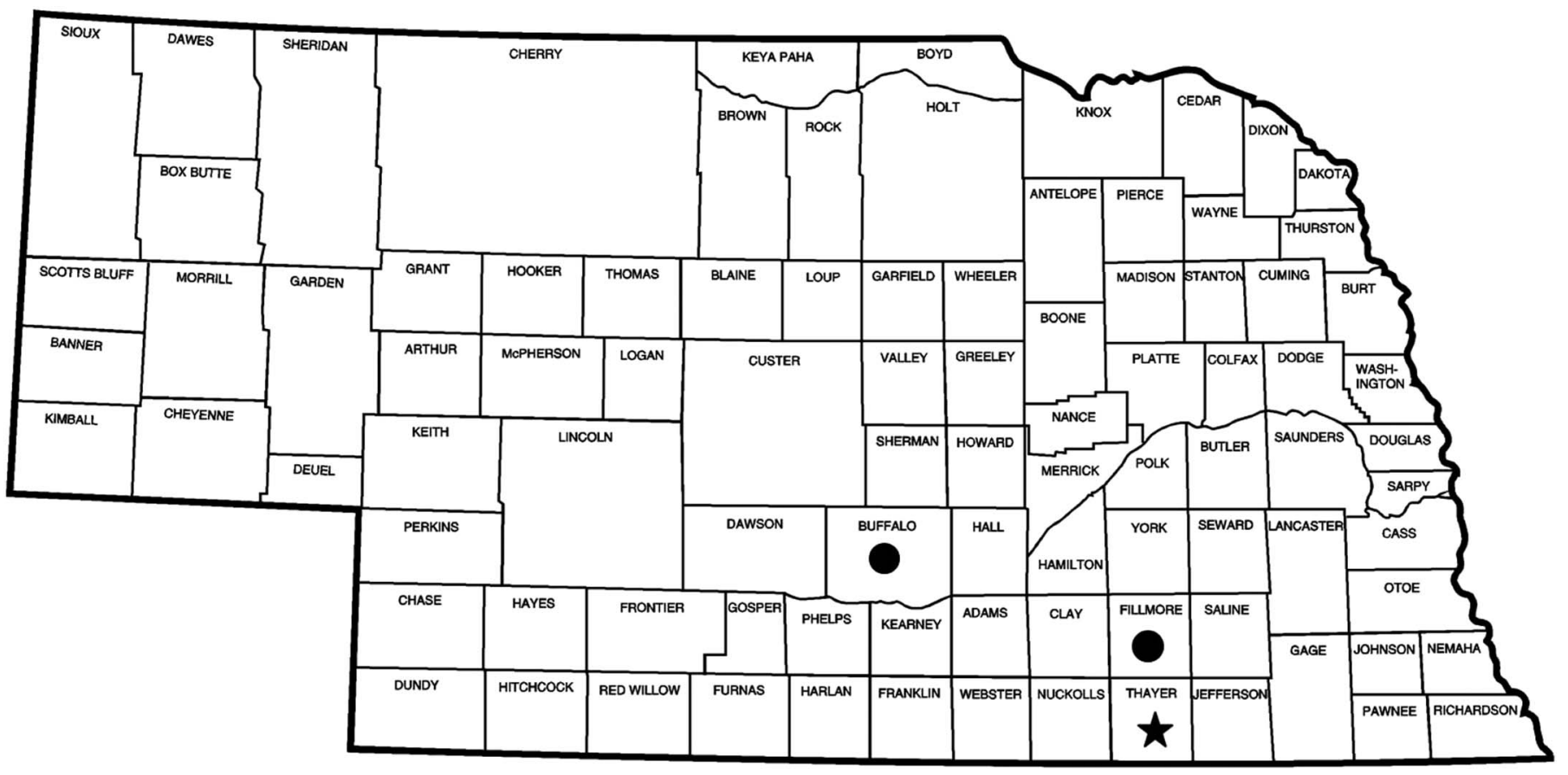

Figure 1. South-central Nebraska counties from which suspected glyphosate-resistant $(\star)$ and glyphosate-susceptible $(\mathbf{\bullet})$ Palmer amaranth seeds were collected. 
rates were used: $0,0.25 \times, 0.5 \times, 1 \times, 2 \times, 4 \times, 8 \times, 16 \times$, $32 x$, and $64 x$, where $1 \times$ indicates the recommended field rate of glyphosate $\left(870 \mathrm{~g}\right.$ ae ha $\left.{ }^{-1}\right)$. The three Palmer amaranth biotypes used were $R, S_{1}$, and $S_{2}$. The experiment was repeated twice under similar growing conditions mentioned above. A single Palmer amaranth plant per pot was considered an experimental unit. Seedlings were treated with glyphosate (Roundup PowerMax ${ }^{\circledR}$, Monsanto Company, 800 North Lindberg Ave., St. Louis, MO) at the six- to seven-leaf stage $(8$ to $10 \mathrm{~cm}$ tall). Each glyphosate treatment was prepared in distilled water and mixed with $0.25 \% \mathrm{v} / \mathrm{v}$ nonionic surfactant (Induce ${ }^{\circledR}$, Helena Chemical Co., Collierville, TN) and $2.5 \% \mathrm{wt} / \mathrm{v}$ ammonium sulfate (DSM Chemicals North America Inc., Augusta, GA).

Herbicide treatments were applied using a single-tip chamber sprayer (DeVries Manufacturing Corp, Hollandale, MN 56045) fitted with a 8001E nozzle (TeeJet ${ }^{\circledR}$, Spraying Systems Co., Wheaton, IL 60187) calibrated to deliver $190 \mathrm{~L} \mathrm{ha}^{-1}$ carrier volume at $207 \mathrm{kPa}$. Palmer amaranth control was assessed visually at 7,14 , and $21 \mathrm{~d}$ after treatment (DAT) using a scale ranging from $0 \%$ (no control) to $100 \%$ (complete control or death of plants). These control scores were based on symptoms such as chlorosis, necrosis, stand loss, and stunting of plants compared with non-treated control plants. Aboveground biomass of each Palmer amaranth plant was harvested at 21 DAT and oven-dried for $4 \mathrm{~d}$ at $65 \mathrm{C}$, and dry weights (biomass) were determined. The biomass data were converted into percent biomass reduction compared with the nontreated control plants (Wortman 2014, using the following formula:

$$
\operatorname{Biomassreduction}(\%)=\frac{(\bar{C}-B)}{\bar{C}} \times 100,
$$

where $\bar{C}$ is the mean biomass of the four non-treated control replicates and $B$ is the biomass of an individual treated experimental unit. Using the drc 2.3 package $\mathbf{c}$ in $\mathrm{R}$ statistical software version 3.1.0 ( $\mathrm{R}$ Foundation for Statistical Computing, Vienna, Austria), a threeparameter log-logistic function was used to determine the effective dose of glyphosate needed to control each Palmer amaranth biotype by $50 \%\left(\mathrm{ED}_{50}\right)$ and $90 \%$ $\left(\mathrm{ED}_{90}\right)$ (Knezevic et al. 2007):

$$
Y=\frac{d}{1+\exp [b(\log x-\log e)]},
$$

where $Y$ is the percent control score or percent aboveground biomass reduction, $x$ is the herbicide rate, $\mathrm{d}$ is the upper limit, $e$ represents the $\mathrm{ED}_{50}$ or $\mathrm{ED}_{90}$ value, and $b$ represents the relative slope around the parameter $e$. The level of resistance was calculated by dividing the $\mathrm{ED}_{90}$ value of the resistant biotype by that of the susceptible biotypes, $S_{1}$ and $S_{2}$. Where the $E_{90}$ values for $S_{1}$ and $S_{2}$ were dissimilar, a range of resistance levels is provided.

Genomic DNA Isolation. The putative GR and GS Palmer amaranth plants were grown under greenhouse conditions at the University of NebraskaLincoln using the same procedures reported for the whole-plant dose-response study. GR Palmer amaranth plants were sprayed with $0,1 \times, 2 \times$, and $4 \times$ rates of glyphosate using a single-tip chamber sprayer as described in the whole-plant dose-response study. Fresh leaf tissue was collected from untreated GS and GR as well as from treated GR Palmer amaranth plants that survived the $1 \times, 2 \times$, and $4 \times$ rates of glyphosate at 21 DAT. The harvested leaf tissue was immediately flash frozen in liquid nitrogen $(-195.79 \mathrm{C})$ and stored at $-80 \mathrm{C}$ for genomic DNA (gDNA) isolation and extracted from frozen leaf tissue $(100 \mathrm{mg})$ using an EZNA ${ }^{\circledR}$ Plant DNA kit (Omega bio-tek, Norcross, GA) according to the manufacturer's instructions. The isolated gDNA was then quantified on a NanoDrop ${ }^{\circledR}$ spectrophotometer (Thermo Fisher Scientific, Waltham, MA).

EPSPS Gene Amplification. A quantitative realtime polymerase chain reaction (qPCR) was performed using a StepOnePlus ${ }^{\mathrm{TM}}$ real-time detection system (Applied Biosystems, Waltham, MA) to determine the EPSPS gene copy number in plants that survived glyphosate application. The qPCR reaction mix $(14 \mu \mathrm{L})$ consisted of $8 \mu \mathrm{L}$ of PowerUp ${ }^{\mathrm{TM}}$ SYBR $^{\mathrm{TM}}$ Green master mix (Applied Biosystems), $2 \mu \mathrm{L}$ each of forward and reverse primers $(5 \mu \mathrm{M})$, and $2 \mu \mathrm{L}$ of gDNA $(20 \mathrm{ng} / \mu \mathrm{L})$. The qPCR reaction plate (96-well) was set up with three technical and three biological replicates. The qPCR conditions were $95 \mathrm{C}$ for $15 \mathrm{~min}, 40$ cycles of $95 \mathrm{C}$ for $30 \mathrm{~s}$, and an annealing at $60 \mathrm{C}$ for $1 \mathrm{~min}$. The forward and reverse primers used for amplifying the EPSPS gene were: 5'-ATGTTGGACGCTCTCAG AACTCTTGGT-3' and 5'-TGAATTTCCTCCAG CAACGGCAA-3' with an amplicon size of $195 \mathrm{bp}$ (Gaines et al. 2010). $\beta$-Tubulin was used as a reference gene for normalizing the qPCR data. The forward and reverse primers used for amplifying the $\beta$-tubulin gene were: 5'-ATGTGGGATGCCAAGAACATGAT GTG-3' and 5'-TCCACTCCACAAAGTAGGAAG 
AGTTCT-3' with an amplicon size of 157 bp (Godar et al. 2015). A melt curve profile was included following the thermal cycling protocol to determine the specificity of the qPCR products. Relative EPSPS copy number was assessed using the formula for fold induction $\left(2^{-\Delta \Delta \mathrm{Ct}}\right.$ ) (Pfaffl 2001). The EPSPS copies were measured relative to the calibrator sample SNT1 (a known glyphosate-susceptible sample).

Response to POST Corn and Soybean Herbicides. The response of GR Palmer amaranth to POST corn and soybean herbicides was evaluated. Treatments included registered POST corn (Table 1) and soybean (Table 2) herbicides applied at the rates recommended on the labels. Plants were grown under greenhouse conditions at the University of NebraskaLincoln using the same procedures reported for the whole-plant dose-response study. Separate experiments were conducted for POST corn and soybean herbicides in randomized complete block designs with four replications. Herbicides were applied when GR Palmer amaranth plants were 8 to $10 \mathrm{~cm}$ tall, using the same chamber-track sprayer used in the whole-plant doseresponse study. Palmer amaranth control scores were recorded at 7,14 , and 21 DAT on a scale of $0 \%$ to $100 \%$ as described in the dose-response study. At 21 DAT, plants were cut at the soil surface and oven-dried for $4 \mathrm{~d}$ at $65 \mathrm{C}$, after which dry biomass weights were recorded. Percent biomass reduction of treated plants was calculated using Equation 1. Experiments were repeated twice.

Data were subjected to ANOVA using the PROC GLIMMIX procedure in SAS $^{\circledR}$ version 9.3 (SAS Institute Inc, Cary, NC). Data for corn and soybean

Table 1. Details of POST corn herbicides used in a greenhouse study at the University of Nebraska-Lincoln to determine response of glyphosate-resistant Palmer amaranth.

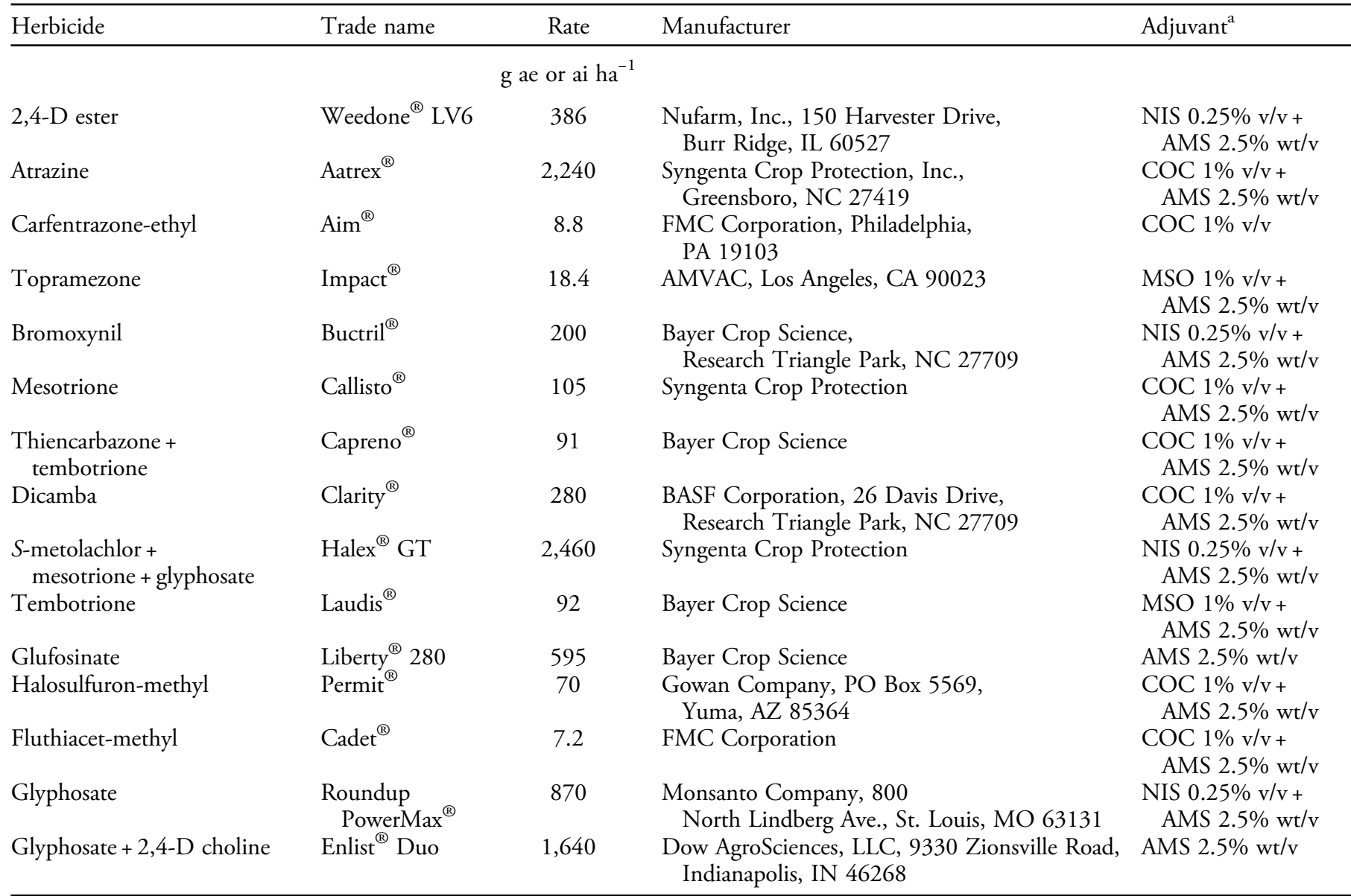

\footnotetext{
${ }^{a}$ Abbreviations: AMS, ammonium sulfate (DSM Chemicals North America Inc., Augusta, GA); COC, crop oil concentrate (Agridex ${ }^{\circledR}$, Helena Chemical Co., Collierville, TN); MSO, methylated seed oil (Southern Ag Inc., Suwanee, GA); NIS, nonionic surfactant (Induce $^{\circledR}$, Helena Chemical Co., Collierville, TN).
} 
Table 2. Details of POST soybean herbicides used in a greenhouse study at the University of Nebraska-Lincoln to determine response of glyphosate-resistant Palmer amaranth.

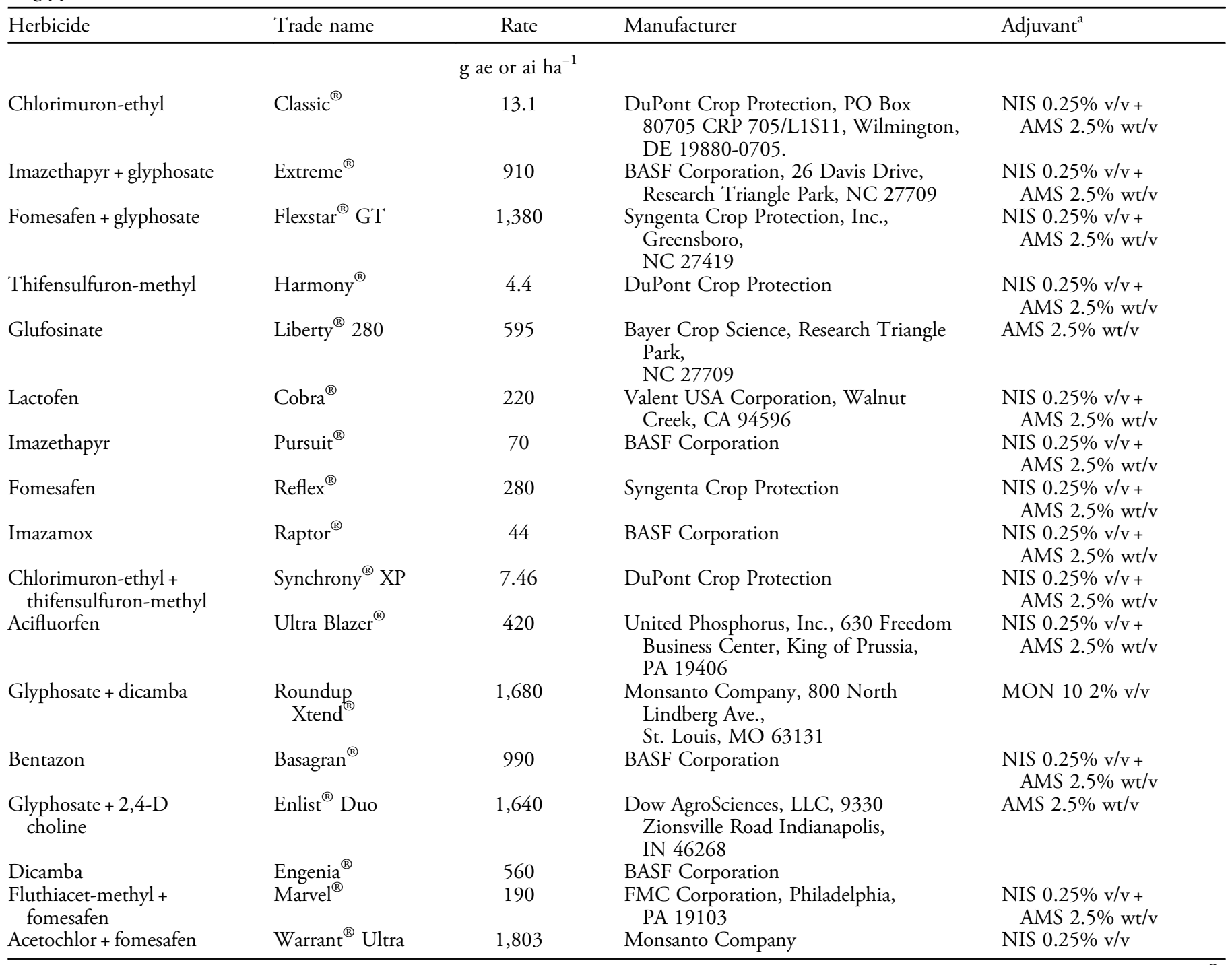

${ }^{a}$ Abbreviations: AMS, ammonium sulfate (DSM Chemicals North America Inc., Augusta, GA); NIS, nonionic surfactant (Induce ${ }^{\circledR}$, Helena Chemical Co., Collierville, TN). MON 10 (Monsanto Company, 800 North Lindberg Ave., St. Louis, MO) is an adjuvant to be used at $2 \% \mathrm{v} / \mathrm{v}$ with Roundup Xtend ${ }^{\circledR}$.

herbicides were analyzed separately to determine the difference in Palmer amaranth response to different herbicide treatments. Control score and biomass reduction data were analyzed without values from the non-treated control plants. Herbicide treatment, DAT, experimental run, and their interactions were considered fixed effects, whereas replication was considered a random effect in the model. Before analysis, data were tested for normality and homogeneity of variance using PROC UNIVARIATE. Normality and homogeneity of variance assumptions were met; therefore, no data transformation was needed. Control score and percent biomass reduction means were separated using Fisher's LSD test at $\mathrm{P} \leq 0.05$.

\section{Results and Discussion}

Whole-Plant Dose-Response Bioassay. Experiment by treatment interactions for Palmer amaranth control $(\mathrm{P}=0.061)$ and biomass reduction $(\mathrm{P}=$ 0.083 ) were not significant; therefore, data from both experiments were combined. Glyphosate applied at the label-recommended rate $\left(870 \mathrm{~g}\right.$ ae $\left.\mathrm{ha}^{-1}\right)$ controlled both GS Palmer amaranth biotypes 96\%, whereas the GR biotype was only 19\% controlled (Figure 2). 


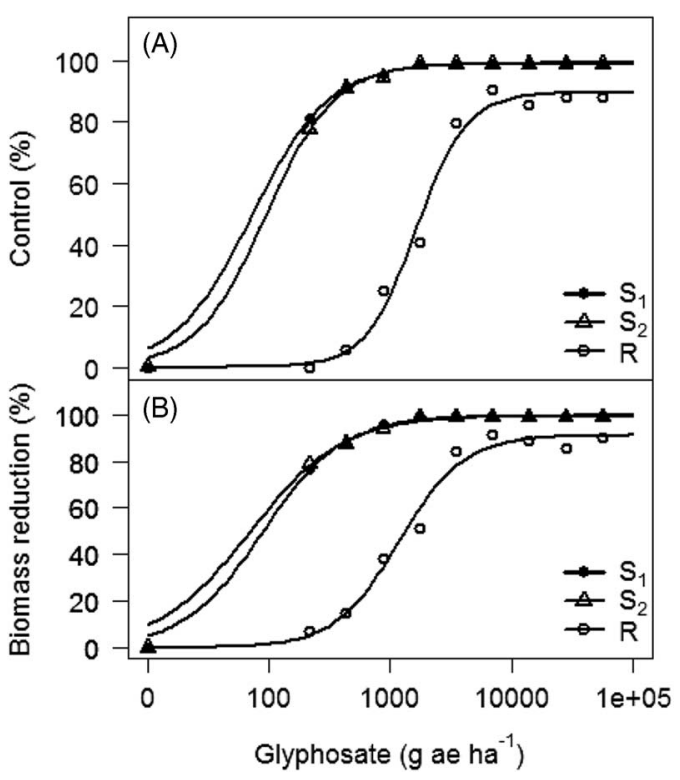

Figure 2. Dose-response curves of glyphosate-resistant $(\mathrm{R})$ and -susceptible $\left(S_{1}\right.$ and $\left.S_{2}\right)$ biotypes from Nebraska. (A) Control at 21 days after treatment, and (B) percent biomass reduction at 21 days after treatment, in a greenhouse whole-plant glyphosate dose-response study conducted at the University of NebraskaLincoln. Percent biomass reduction was calculated using the following equation: Biomassreduction $(\%)=\frac{(\bar{C}-B)}{\bar{C}} \times 100$, where $\bar{C}$ is the mean biomass of the four non-treated control replicates, and $B$ is the biomass of an individual treated experimental unit.

To achieve 50\% and 90\% control of the GR Palmer amaranth biotype required glyphosate rates of 1,787 and 14,420 $\mathrm{g}$ ae ha ${ }^{-1}, 2$ - and 17-fold the labeled rate, respectively. The GR Palmer amaranth biotype was controlled only $90 \%$ by the highest glyphosate rate $\left(55,040 \mathrm{~g} \mathrm{ha}^{-1}\right)$ tested in this study. The $\mathrm{ED}_{50}$ and $\mathrm{ED}_{90}$ values of the two susceptible biotypes were similar, ranging from 73 to $94 \mathrm{~g} \mathrm{ha}^{-1}$ and 360 to $393 \mathrm{~g} \mathrm{ha}^{-1}$, respectively. On the basis of $\mathrm{ED}_{90}$ values, the GR biotype had a 37- to 40-fold level of resistance depending on the susceptible biotype being used for comparison (Table 3). Culpepper et al. (2006) reported 50\% control of a GR Palmer amaranth biotype from Georgia with glyphosate applied at $1,200 \mathrm{~g} \mathrm{ha}^{-1}$, and Norsworthy et al. (2008) reported $50 \%$ control of a GR Palmer amaranth biotype from Arkansas with glyphosate applied at $2,820 \mathrm{~g} \mathrm{ha}^{-1}$, 1.57-fold higher application rate than that observed in this study $\left(1,787 \mathrm{~g} \mathrm{ha}^{-1}\right)$.

Dose-response curves for GR Palmer amaranth biomass reduction indicated similar levels of resistance (35- to 36-fold) indicated by $\mathrm{ED}_{90}$ values based on visual control scores (Figure 2, Table 4). GR Palmer amaranth biomass was reduced to $50 \%$ and $90 \%$ at 1,319 and $16,797 \mathrm{~g} \mathrm{ha}^{-1}$ glyphosate rates, respectively (Table 4). Similarly, Nandula et al. (2012) observed a $50 \%$ biomass reduction of two GR biotypes from Mississippi with glyphosate applied at 1,520 and $1,300 \mathrm{~g} \mathrm{ha}^{-1}$. In contrast, Mohseni-Moghadam et al. (2013b) reported $50 \%$ biomass reduction of a GR Palmer amaranth biotype from New Mexico with glyphosate applied at $458 \mathrm{~g} \mathrm{ha}^{-1}$, about 2.9-fold lower application rate than the level observed in this study.

EPSPS Gene Amplification. In the current study, the EPSPS copy number in Palmer amaranth was measured relative to two known glyphosate susceptible populations from Buffalo County and

Table 3. Estimates of regression parameters and glyphosate dose required for $50 \%\left(\mathrm{ED}_{50}\right)$ and $90 \%$ (ED 90 ) control of Palmer amaranth biotypes, 21 days after treatment, in a greenhouse whole-plant glyphosate dose-response study at the University of Nebraska-Lincoln.

\begin{tabular}{|c|c|c|c|c|c|}
\hline \multirow{3}{*}{ Palmer amaranth biotype } & \multicolumn{5}{|c|}{ Glyphosate } \\
\hline & \multicolumn{2}{|c|}{ Regression parameters $( \pm S E)^{b}$} & $\mathrm{ED}_{50}( \pm \mathrm{SE})^{\mathrm{a}}$ & $\mathrm{ED}_{90}( \pm \mathrm{SE})^{\mathrm{a}}$ & Resistance level $^{\mathrm{c}}$ \\
\hline & $\mathrm{b}$ & $\mathrm{d}$ & $\longrightarrow$ & & \\
\hline $\begin{array}{l}\mathrm{S}_{1} \\
\mathrm{~S}_{2} \\
\mathrm{R}\end{array}$ & $\begin{array}{l}-1.37( \pm 0.22) \\
-1.54( \pm 0.13) \\
-2.10( \pm 0.26)\end{array}$ & $\begin{array}{r}99.26( \pm 0.59) \\
99( \pm 0.35) \\
90( \pm 2.29)\end{array}$ & $\begin{array}{l}72.88( \pm 14.50) \\
94.39( \pm 8) \\
1,787( \pm 135)\end{array}$ & $\begin{aligned} 360 & ( \pm 34) \\
393 & ( \pm 22) \\
14,420 & ( \pm 4158)\end{aligned}$ & $\begin{array}{c}- \\
- \\
37 \times \text { to } 40 x\end{array}$ \\
\hline
\end{tabular}

${ }^{a}$ Abbreviations: $\mathrm{ED}_{50}$, effective glyphosate dose required to control $50 \%$ population at 21 days after treatment; ED 90 , effective glyphosate dose required to control $90 \%$ population at 21 days after treatment; $S_{1}$, glyphosate-susceptible Palmer amaranth biotype collected from a field in Buffalo County, NE; $S_{2}$, glyphosate-susceptible Palmer amaranth biotype collected from a field in Fillmore County, NE; R, glyphosate-resistant Palmer amaranth biotype collected from a field in Thayer County, NE; SE, standard error.

b Regression parameters $b$ and $d$ of three-parameter log-logistic model were obtained using the nonlinear least-square function of the statistical software R.

${ }^{\mathrm{c}}$ Resistance level was calculated by dividing the $\mathrm{ED}_{90}$ value of the resistant Palmer amaranth biotype by that of the susceptible Palmer amaranth biotypes $\left(S_{1}\right.$ and $\left.S_{2}\right)$. A range of resistance levels is provided due to a difference in $E_{90}$ values for $S_{1}$ and $S_{2}$. 
Table 4. Estimates of regression parameters and glyphosate dose required for $50 \%\left(\mathrm{ED}_{50}\right)$ and $90 \%\left(\mathrm{ED}_{90}\right)$ aboveground biomass reduction of Palmer amaranth biotypes, 21 days after treatment, in a greenhouse whole-plant glyphosate dose-response study at the University of Nebraska-Lincoln.

\begin{tabular}{|c|c|c|c|c|c|}
\hline \multirow{3}{*}{ Palmer amaranth biotype ${ }^{a}$} & \multicolumn{5}{|c|}{ Glyphosate } \\
\hline & \multicolumn{2}{|c|}{ Regression parameters $( \pm \text { SE })^{\mathrm{b}}$} & $\mathrm{ED}_{50}( \pm \mathrm{SE})^{\mathrm{a}}$ & $\mathrm{ED}_{90}( \pm \mathrm{SE})^{\mathrm{a}}$ & Resistance level $^{\mathrm{c}}$ \\
\hline & $\mathrm{b}$ & $\mathrm{d}$ & \multicolumn{2}{|c|}{-g ae ha ${ }^{-1}$} & \\
\hline $\begin{array}{l}\mathrm{S}_{1} \\
\mathrm{~S}_{2} \\
\mathrm{R}\end{array}$ & $\begin{array}{l}-1.33( \pm 0.2) \\
-1.14( \pm 0.23) \\
-1.64( \pm 0.16)\end{array}$ & $\begin{aligned} 99.45 & ( \pm 0.78) \\
99.57 & ( \pm 1) \\
91 & ( \pm 2.01)\end{aligned}$ & $\begin{aligned} 89 & ( \pm 14.8) \\
69.79 & ( \pm 17.7) \\
1,319 & ( \pm 100)\end{aligned}$ & $\begin{aligned} 463 & ( \pm 57) \\
476 & ( \pm 82) \\
16,797 & ( \pm 4674)\end{aligned}$ & $\begin{array}{c}- \\
- \\
35 x \text { to } 36 x\end{array}$ \\
\hline
\end{tabular}

${ }^{a}$ Abbreviations: $\mathrm{ED}_{50}$, effective glyphosate dose required for $50 \%$ reduction of dry shoot biomass of Palmer amaranth biotypes at $21 \mathrm{~d}$ after treatment; $\mathrm{ED}_{90}$, effective dose required for $90 \%$ reduction of dry shoot biomass of Palmer amaranth biotypes at $21 \mathrm{~d}$ after treatment; $S_{1}$, glyphosate-susceptible Palmer amaranth biotype collected from a field in Buffalo County, NE; $S_{2}$, glyphosate-susceptible Palmer amaranth biotype collected from a field in Fillmore County, NE; R, glyphosate-resistant Palmer amaranth biotype collected from a field in Thayer County, NE; SE, standard error.

${ }^{b}$ Regression parameters $\mathrm{b}$ and $\mathrm{d}$ of three-parameter log-logistic model were obtained using the nonlinear least-square function of the statistical software R.

${ }^{\mathrm{c}}$ Resistance level was calculated by dividing the $\mathrm{ED}_{90}$ value of the resistant Palmer amaranth biotype by that of susceptible Palmer amaranth biotypes $\left(S_{1}\right.$ and $\left.S_{2}\right)$. A range of resistance levels is provided due to a difference in $E D_{90}$ values for $S_{1}$ and $S_{2}$.

Fillmore County, NE ( $S_{1}$ and $S_{2}$, respectively) using suspected GR biotype) to 105 (G1X2, suspected GR $\beta$-tubulin as a reference gene. EPSPS gene copy biotype survived treatment with $1 \mathrm{x}$ glyphosate rate) numbers ranging from 32 (GNT1, non-treated were found in Palmer amaranth plants that survived

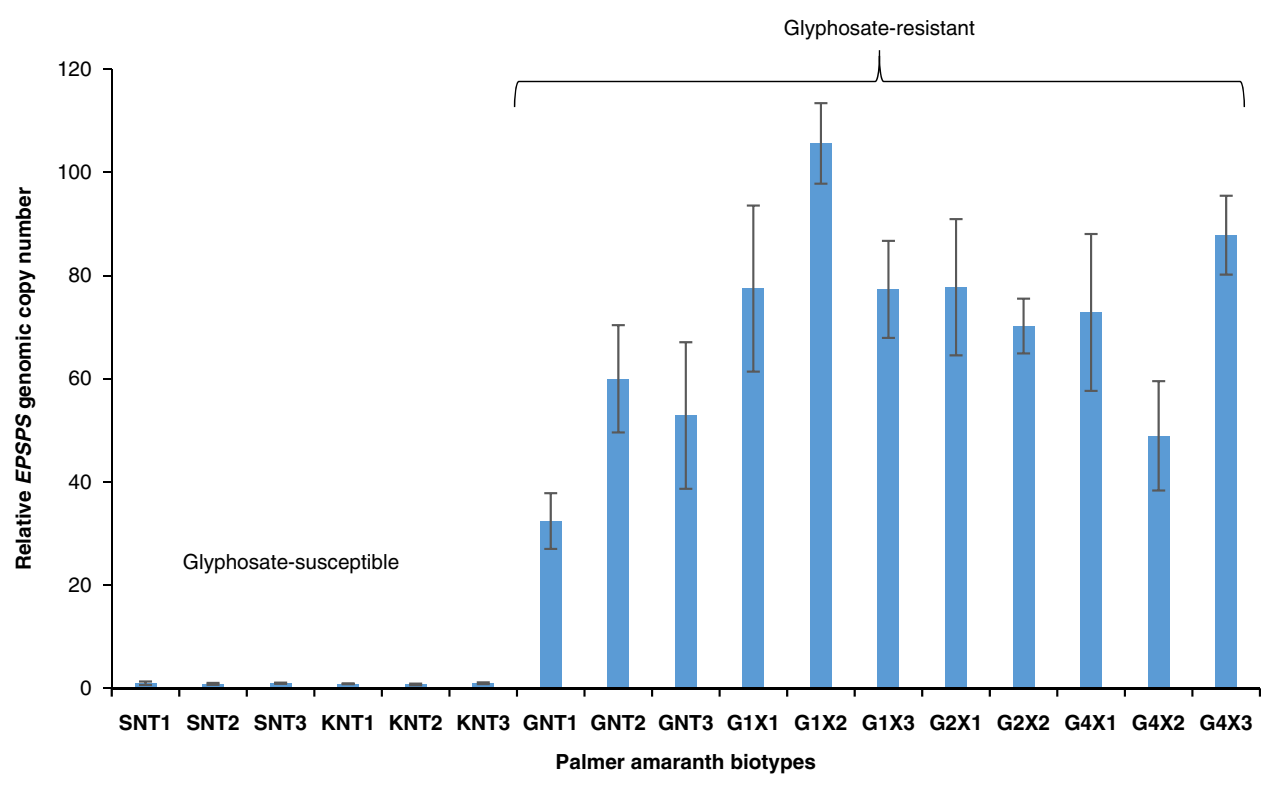

Figure 3. The EPSPS gene copy numbers of glyphosate-resistant and glyphosate-susceptible Palmer amaranth biotypes, relative to susceptible samples. Biotypes SNT1, SNT2, SNT3, KNT1, KNT2, and KNT3 were glyphosate-susceptible. Biotypes G1x1, G1x2, and G1x3 survived treatment with $1 \times$ glyphosate $\left(870 \mathrm{~g}^{2} \mathrm{ha}^{-1}\right)$, biotypes G2x1 and G2x2 survived treatment with $2 \times$ glyphosate, and biotypes G4x1, G4x2, and G4x3 survived treatment with 4x glyphosate. Sample SNT1, which has a single copy of the EPSPS gene, was used as a calibrator for determining the relative ESPSP gene copy numbers. Error bars represent the standard error from the mean ( $n=3$ technical replicates). The qPCR data were normalized using $\beta$-tubulin as a reference gene. Abbreviations: EPSPS, 5-enolpyruvylshikimate-3-phosphate; GNT, glyphosate non-treated suspected glyphosate-resistant Palmer amaranth plant samples from Thayer county, NE; KNT, glyphosate non-treated glyphosate-susceptible Palmer amaranth plant samples collected from Buffalo County, NE; qPCR, quantitative real-time polymerase chain reaction; SNT, glyphosate non-treated glyphosate-susceptible Palmer amaranth plant samples collected from Fillmore County, NE. 
glyphosate application (Figure 3), suggesting that amplification of the EPSPS gene contributes to glyphosate resistance in the Palmer amaranth biotype from Nebraska. Similar to the GR Palmer amaranth biotype from Georgia (Gaines et al. 2011), Palmer amaranth plants that had $>30$ EPSPS copies were able to survive and confer resistance to the labelrecommended rate of glyphosate. More recently, GR Palmer amaranth from Kansas was also found to have 50 to 140 EPSPS copies (Varanasi et al. 2015), and a biotype from New Mexico with 6 to 8 EPSPS copies survived treatment with the labeled rate of glyphosate (Mohseni-Moghadam et al. 2013a). EPSPS gene amplification also contributes to glyphosate resistance in other members of the Amaranthaceae family; for example, Nandula et al. (2014) reported 33 to 37 copies of the EPSPS gene in GR spiny amaranth (Amaranthus spinosus L.) from Mississippi. In a multistate study, 4 to 10 EPSPS gene copies were reported in several populations of GR common waterhemp [Amaranthus tuberculatus (Moq.) Sauer] collected from several states in the Midwest (Chatham et al. 2015a). Similarly, Sarangi (2016) reported an average of 5.3 EPSPS gene copies in a GR common waterhemp biotype from Nebraska. These reports suggest that EPSPS gene amplification is a common glyphosate resistance mechanism in Amaranthaceae.

Response to POST Corn Herbicides. Experiment by treatment interactions for Palmer amaranth control $(\mathrm{P}=0.09)$ and biomass reduction $(\mathrm{P}=$ 0.102 ) in response to corn herbicides were not significant; therefore, data from both experiments were combined. The GR Palmer amaranth biotype was very sensitive to glufosinate, which provided $90 \%$ and $99 \%$ control at 7 and 21 DAT, respectively. Similarly, previous studies have reported $>95 \%$ Palmer amaranth control with glufosinate (Jhala et al. 2014; Norsworthy et al. 2008; Salas et al. 2016). At 21 DAT, dicamba and 2,4-D ester, applied alone, controlled Palmer amaranth $81 \%$ and $74 \%$, respectively, and a 2,4-D choline plus glyphosate premix formulated for 2,4-D plus glyphosate-tolerant corn and soybean provided $89 \%$ control. Craigmyle et al. (2013) reported $97 \%$ control of 10 to $15 \mathrm{~cm}$ tall common waterhemp, a species closely related to Palmer amaranth, with tank-mixed application of glufosinate and 2,4-D choline at 450 and $840 \mathrm{~g} \mathrm{ae} \mathrm{ha}^{-1}$, respectively, in 2,4-D plus glufosinate-tolerant soybean. Jhala et al. (2014) have further reported $83 \%$ to $97 \%$ control of three Palmer amaranth biotypes with dicamba or 2,4-D ester applied at $560 \mathrm{~g}$ ae ha $\mathrm{ha}^{-1}$. Similarly, Norsworthy et al. (2008) reported $>95 \%$ control of GR palmer amaranth with dicamba and 2,4-D amine applied alone at 280 and $560 \mathrm{~g} \mathrm{ha}^{-1}$, respectively; however, the reduced control $(74 \%)$ of GR Palmer amaranth with 2,4-D ester in this study might be due to the use of the lowest labelrecommended rate $\left(386 \mathrm{~g} \mathrm{ha}^{-1}\right)$.

At 7 and 21 DAT, HPPD-inhibiting herbicides (mesotrione, topramezone, and tembotrione, used individually) failed to control GR Palmer amaranth $(\leq 60 \%)$. Control was not improved with premixed applications of tembotrione and thiencarbazone (51\%), or with mesotrione plus $S$-metolachlor plus glyphosate $(33 \%)$ at 21 DAT. Jhala et al. (2014) also reported $55 \%$ to $75 \%$ control of HPPD- and PSIIinhibitor-resistant Palmer amaranth and $\geq 84 \%$ control of two susceptible Palmer amaranth biotypes from Nebraska with POST application of mesotrione or topramezone at rates similar to those tested in this study (105 and $18.4 \mathrm{~g}$ ai ha ${ }^{-1}$, respectively). Similarly, Norsworthy et al. (2008) reported $\geq 79 \%$ control of GR and GS Palmer amaranth biotypes from Arkansas in a greenhouse study with a POST application of mesotrione at $105 \mathrm{~g} \mathrm{ha}^{-1}$.

At 7 and 21 DAT, PSII-inhibitors (atrazine or bromoxynil) controlled GR Palmer amaranth $\leq 25 \%$ (Table 5). In contrast, previous studies reported $100 \%$ control of glyphosate- and PPO-inhibitorresistant Palmer amaranth biotypes from Arkansas with a POST application of atrazine at the rates tested in this study $\left(2,240 \mathrm{~g} \mathrm{ha}^{-1}\right)$ (Norsworthy et al. 2008; Salas et al. 2016). Jhala et al. (2014) reported $<25 \%$ control of HPPD- and PSII-inhibitorresistant Palmer amaranth and $45 \%$ to $75 \%$ control of two susceptible Palmer amaranth biotypes from Nebraska with atrazine applied at $560 \mathrm{~g}$ ai ha ${ }^{-1}$. Bromoxynil is not very effective for Palmer amaranth control; for instance, Corbett et al. (2004) reported $<60 \%$ control of 8 to $10 \mathrm{~cm}$ tall Palmer amaranth with bromoxynil applied at $420 \mathrm{~g}$ ae ha ${ }^{-1}$, twice the rate used in this study. At 7 DAT, carfentrazoneethyl and fluthiacet-methyl (PPO-inhibitors) controlled Palmer amaranth $<60 \%$; however, control decreased to $\leq 30 \%$ at 21 DAT. In contrast, Jhala et al. (2014) observed variable control of three Palmer amaranth biotypes (38\% to $95 \%)$ at 21 DAT with fluthiacet-methyl at $7.2 \mathrm{~g}^{\text {ai }} \mathrm{ha}^{-1}$ in a greenhouse study, providing evidence for the reduced 
Table 5. Effects of POST corn herbicide treatments on glyphosate-resistant Palmer amaranth control 7 and 21 days after treatment (DAT), and biomass reduction 21 DAT.

\begin{tabular}{|c|c|c|c|c|}
\hline \multirow[b]{2}{*}{ Herbicide $^{\mathrm{a}}$} & \multirow[b]{2}{*}{ Rate } & \multicolumn{2}{|c|}{ Control $^{\mathrm{b}, \mathrm{c}}$} & \multirow[b]{2}{*}{ Biomass reduction $^{\mathrm{b}}$, } \\
\hline & & 7 DAT & $21 \mathrm{DAT}$ & \\
\hline & $\mathrm{g}$ ae or ai ha ${ }^{-1}$ & - & $\%-$ & . \\
\hline 2,4-D & 386 & $63 \mathrm{~b}$ & $74 \mathrm{bc}$ & $70 \mathrm{~cd}$ \\
\hline Atrazine & 2,240 & $25 \mathrm{~g}$ & $23 \mathrm{ef}$ & $32 \mathrm{fgh}$ \\
\hline Carfentrazone-ethyl & 8.8 & $49 \mathrm{~cd}$ & $30 \mathrm{e}$ & $48 \mathrm{ef}$ \\
\hline Topramezone & 18.4 & $43 \mathrm{de}$ & $58 \mathrm{~cd}$ & $75 \mathrm{bcd}$ \\
\hline Bromoxynil & 200 & $11 \mathrm{~h}$ & $9 \mathrm{fg}$ & $16 \mathrm{hi}$ \\
\hline Mesotrione & 105 & $44 \mathrm{de}$ & $54 \mathrm{~d}$ & $73 \mathrm{bcd}$ \\
\hline Thiencarbazone + tembotrione & 91 & $38 \mathrm{ef}$ & $51 \mathrm{~d}$ & $72 \mathrm{bcd}$ \\
\hline Dicamba & 280 & $62 \mathrm{~b}$ & $81 \mathrm{~b}$ & $87 \mathrm{abc}$ \\
\hline$S$-metolachlor + mesotrione + glyphosate & 2,460 & $30 \mathrm{fg}$ & $33 \mathrm{e}$ & $64 \mathrm{de}$ \\
\hline Tembotrione & 92 & $44 \mathrm{de}$ & $60 \mathrm{~cd}$ & $78 \mathrm{bcd}$ \\
\hline Glufosinate & 595 & $90 \mathrm{a}$ & $99 \mathrm{a}$ & $99 \mathrm{a}$ \\
\hline Halosulfuron-methyl & 70 & $30 \mathrm{gf}$ & 18 ef & $20 \mathrm{gh}$ \\
\hline Fluthiacet-methyl & 7.2 & $58 \mathrm{bc}$ & $27 \mathrm{e}$ & $39^{\circ} \mathrm{gf}$ \\
\hline Glyphosate & 870 & $14 \mathrm{~h}$ & $19 \mathrm{ef}$ & $26 \mathrm{gh}$ \\
\hline Glyphosate $+2,4-\mathrm{D}$ choline & 1,640 & $70 \mathrm{~b}$ & $89 \mathrm{ab}$ & $92 \mathrm{ab}$ \\
\hline
\end{tabular}

${ }^{a}$ Ammonium sulfate (DSM Chemicals North America Inc., Augusta, GA) at $2.5 \%$ wt/v was added to all herbicide treatments except carfentrazone-ethyl; nonionic surfactant (Induce ${ }^{\circledR}$. Helena Chemical Co., Collierville, TN) at $0.25 \%$ v/v was added to $2,4-\mathrm{D}$, bromoxynil, S-metolachlor + mesotrione + glyphosate, and glyphosate treatments; crop oil concentrate (Agridex ${ }^{\circledR}$, Helena Chemical Co., Collierville, TN) at $1 \%$ v/v was added to atrazine, carfentrazone-ethyl, mesotrione, thiencarbazone + tembotrione, dicamba, halosulfuron-methyl, and fluthiacet-methyl treatments; and methylated seed oil (Southern Ag Inc., Suwanee, GA) at 1\% v/v was added to topramezone and tembotrione treatments.

${ }^{\mathrm{b}}$ Means within columns with no common letter(s) are significantly different according to Fisher's protected LSD test where $\mathrm{P} \leq 0.05$.

${ }^{c}$ Percent control and biomass reduction data of non-treated control were not included in analysis. Biomass reduction was calculated based on comparison with the average biomass of the non-treated control using the following equation: Biomassreduction $(\%)=\frac{(\bar{C}-B)}{\bar{C}} \times 100$, where $\bar{C}$ is the mean biomass of the four non-treated control replicates and $B$ is the biomass of an individual treated experimental unit.

sensitivity of GR Palmer amaranth biotypes to PPOinhibitors. Reddy et al. (2014) also reported $55 \%$ to 96\% control of three Palmer amaranth biotypes at 21 DAT with fluthiacet-methyl and carfentrazone at rates used in this study $\left(7.2\right.$ and $8.8 \mathrm{~g}$ ai $\mathrm{ha}^{-1}$, respectively). GR Palmer amaranth was $<20 \%$ controlled at 21 DAT by halosulfuron-methyl, one of the ALS inhibitors, which is not surprising given that ALS-inhibitor-resistant weeds have become widespread in the Midwest due to the continuous use of ALS-inhibiting herbicides in corn and soybean (Heap 2016b; Sarangi et al. 2015). Glyphosate applied alone controlled Palmer amaranth $\leq 30 \%$ as observed in the glyphosate dose-response study.

Results of the control scores were reflected in biomass reduction of GR Palmer amaranth. For example, glufosinate resulted in the highest biomass reduction (99\%), which was comparable with 2,4-D choline plus glyphosate (92\%), and dicamba (87\%). All other treatments resulted in $15 \%$ to $80 \%$ biomass reduction. Similarly, Mohseni-Moghadam et al. (2013b) reported no difference in biomass reduction of two Palmer amaranth biotypes at 16 DAT with glufosinate $(>97 \%)$ or dicamba $(88 \%)$ applied POST. Likewise, Jhala et al. (2014) reported $<80 \%$ biomass reduction of HPPD- and PSIIinhibitor-resistant Palmer amaranth with mesotrione, topramezone, atrazine, halosulfuron-methyl, fluthiacet-methyl, or bromoxynil applied POST at 21 DAT.

Response to POST Soybean Herbicides. Experiment by treatment interactions for Palmer amaranth control $(P=0.15)$ and biomass reduction $(P=$ 0.102 ) in response to soybean herbicides were not significant; therefore, data from both experiments were combined. At 21 DAT, GR Palmer amaranth was controlled $20 \%$ to $40 \%$ with ALS-inhibitors (chlorimuron-ethyl, imazethapyr, thifensulfuronmethyl, and Imazamox) and control (23\% to $36 \%)$ 
Table 6. Effects of POST soybean herbicide treatments on glyphosate-resistant Palmer amaranth control 7 and 21 days after treatment (DAT), and biomass reduction at 21 DAT.

\begin{tabular}{|c|c|c|c|c|}
\hline \multirow[b]{2}{*}{ Herbicide $^{\mathrm{a}}$} & \multirow[b]{2}{*}{ Rate } & \multicolumn{2}{|c|}{ Control $^{\mathrm{b}, \mathrm{c}}$} & \multirow[b]{2}{*}{ Reduction in biomass ${ }^{\mathrm{b}, \mathrm{c}}$} \\
\hline & & 7 DAT & $21 \mathrm{DAT}$ & \\
\hline & $\mathrm{g}$ ae or ai ha ${ }^{-1}$ & & 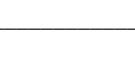 & \\
\hline Chlorimuron-ethyl & 13.1 & $13 \mathrm{de}$ & 39 ef & $37 \mathrm{gf}$ \\
\hline Imazethapyr + glyphosate & 910 & $11 \mathrm{de}$ & 36 ef & $36 \mathrm{gf}$ \\
\hline Fomesafen + glyphosate & 1,380 & $69 \mathrm{ab}$ & $62 \mathrm{bcd}$ & 65 bcde \\
\hline Lactofen & 220 & $55 \mathrm{bc}$ & 49 cde & 62 cde \\
\hline Imazethapyr & 70 & $18 \mathrm{~d}$ & $34 \mathrm{efg}$ & $25 \mathrm{gf}$ \\
\hline Fomesafen & 280 & $69 \mathrm{ab}$ & $72 \mathrm{ab}$ & 64 cde \\
\hline Imazamox & 44 & $9 \mathrm{de}$ & $24 \mathrm{fg}$ & $25 \mathrm{~g}$ \\
\hline Chlorimuron-ethyl + thifensulfuron-methyl & 7.46 & $9 \mathrm{de}$ & $23 \mathrm{fg}$ & $24 \mathrm{gf}$ \\
\hline Acifluorfen & 420 & $56 \mathrm{bc}$ & 48 cde & 49 def \\
\hline Fluthiacet-methyl + fomesafen & 190 & $51 \mathrm{c}$ & $67 \mathrm{bc}$ & 71 abcd \\
\hline Acetochlor + fomesafen & 1,803 & $49 \mathrm{c}$ & $43 \mathrm{def}$ & $47 \mathrm{efg}$ \\
\hline
\end{tabular}

${ }^{a}$ Ammonium sulfate (DSM Chemicals North America Inc., Augusta, GA) at 2.5\% wt/v was added to all herbicide treatments except glyphosate + dicamba and acetochlor + fomesafen; nonionic surfactant (Induce ${ }^{\circledR}$, Helena Chemical Co., Collierville, TN) at $0.25 \%$ v/v was added to all herbicide treatments except glyphosate + dicamba, glyphosate +2,4-D choline, and dicamba. MON 10 (Monsanto Company, 800 North Lindberg Ave., St. Louis, MO) was mixed at 2\% v/v with glyphosate + dicamba.

b Means within columns with no common letter(s) are significantly different according to Fisher's protected LSD test where P $\leq 0.05$.

${ }^{c}$ Percent control and biomass reduction data of non-treated control were not included in analysis. Biomass reduction was calculated based on comparison with the average biomass of the non-treated control using the following equation: Biomassreduction $(\%)=\frac{(\bar{C}-B)}{\bar{C}} \times 100$, where $\bar{C}$ is the mean biomass of the four non-treated control replicates and $B$ is the biomass of an individual treated experimental unit.

was not improved with a premix of imazethapyr plus glyphosate or chlorimuron plus thifensulfuronmethyl (Table 6). In contrast, previous studies have reported $>80 \%$ Palmer amaranth control with imazethapyr or thifensulfuron-methyl at 21 DAT at the rates tested in this study (Horak and Peterson 1995; Sweat et al. 1998). Gossett and Toler (1999) also reported 69\% Palmer amaranth control with chlorimuron-ethyl applied at a rate $\left(9 \mathrm{~g} \mathrm{ha}^{-1}\right)$ lower than that tested in this study $\left(13 \mathrm{~g} \mathrm{ha}^{-\mathrm{P}}\right)$.

The PPO-inhibitors lactofen and acifluorfen controlled Palmer amaranth 55\% at 7 DAT and control decreased to $<50 \%$ at 21 DAT. In contrast, previous studies have reported $60 \%$ to $81 \%$ Palmer amaranth control with acifluorfen applied at a lower rate $\left(280 \mathrm{~g} \mathrm{ha}^{-1}\right)$ than that used in this study, and $85 \%$ to $99 \%$ control with lactofen applied at rates similar to those tested in this study $\left(220 \mathrm{~g} \mathrm{ha}^{-1}\right)$ (Gossett and Toler 1999; Jhala et al. 2014; Sweat et al. 1998). Aulakh et al. (2016) further reported complete control of common waterhemp with acifluorfen and lactofen (420 and $220 \mathrm{~g} \mathrm{ha}^{-1}$, respectively) applied in a greenhouse study at rates similar to those tested here. Fomesafen, another PPO-inhibitor, controlled Palmer amaranth $69 \%$ and $72 \%$ at 7 and 21 DAT, respectively. Likewise, Sweat et al. (1998) reported $74 \%$ to $83 \%$ Palmer amaranth control with fomesafen applied in both field and greenhouse studies at the same rate tested in this study $\left(280 \mathrm{~g} \mathrm{ha}^{-1}\right)$. In contrast, Merchant et al. (2014) reported 89\% to 99\% Palmer amaranth control at 15 DAT in a field study with fomesafen applied at rate similar to that tested in this study. This study showed poor control with premix applications of fomesafen with acetochlor (43\%), glyphosate $(62 \%)$, or fluthiacet-methyl (67\%) at 21 DAT (Table 6).

Bentazon, a PSII-inhibitor, controlled Palmer amaranth $<15 \%$ at 21 DAT. Similarly, previous studies have reported poor efficacy $(<40 \%)$ of bentazon for control of spiny amaranth and Palmer amaranth 
(Grichar 1994, 1997). At 21 DAT, glufosinate, glyphosate plus 2,4-D choline, dicamba, or fomesafen provided $71 \%$ to $92 \%$ GR Palmer amaranth control. Control scores of GR Palmer amaranth were reflected in the biomass reduction results: glufosinate resulted in the highest Palmer amaranth biomass reduction (95\%), and similar biomass reductions were seen with glyphosate plus 2,4-D choline (88\%), dicamba plus glyphosate $(76 \%)$, dicamba $(73 \%)$, and fluthiacet plus fomesafen $(71 \%)$. All other treatments resulted in $20 \%$ to $65 \%$ biomass reduction (Table 6 ).

Practical Implications. The putative GR Palmer amaranth biotype from Thayer County in Nebraska is GR with the level of resistance in the range of 35- to 40-fold compared to the GS Palmer amaranth biotypes. The evolution of GR Palmer amaranth in south-central Nebraska provides cause for concern, considering that glyphosate is the most common herbicide used for weed control in GR corn-soybean cropping systems. While GR Palmer amaranth has been reported in west-central Nebraska, the evolution of GR Palmer amaranth in south-central Nebraska will add management challenges for growers because GR common ragweed (Ambrosia artemisiifolia L.), common waterhemp, giant ragweed (Ambrosia trifida L.), horseweed [Conyza canadensis (L.) Cronq.], and kochia [Kochia scoparia (L.) Schrad.] are already present in the area.

A rapid molecular test, EPSPS gene amplification, has been identified to confirm glyphosate resistance in weeds and has been tested in a Palmer amaranth biotype from Georgia (Gaines et al. 2010), populations of waterhemp from Illinois (Chatham et al. 2015b), and GR waterhemp populations from several states in the Midwest (Chatham et al. 2015a). The molecular test confirmed that the putative GR Palmer amaranth from south-central Nebraska acquired resistance by amplifying the EPSPS gene copy number; however, more research is needed to determine whether other mechanisms of resistance are involved.

The response of the GR Palmer amaranth biotype to POST corn and soybean herbicides suggests that control options are limited. Glufosinate was effective, providing $>95 \%$ control of GR Palmer amaranth, but glufosinate can only be used in glufosinate-tolerant crops. While glufosinate-tolerant corn and soybean are available in the marketplace, current adoption of glufosinate-resistant soybean is limited in Nebraska (Aulakh and Jhala 2015; Chahal and Jhala 2015). Additionally, the reduced sensitivity of GR Palmer amaranth to PSII- (atrazine), HPPD- (mesotrione, tembotrione, and topramezone), ALS- (halosulfuronmethyl), and PPO- (carfentrazone and lactofen) inhibitors justifies the need to conduct a whole-plant dose-response bioassay to confirm and determine the level of multiple resistance (if any) of this biotype to herbicides with these modes of action.

\section{Literature Cited}

Aulakh JS, Chahal PS, Jhala AJ (2016) Glyphosate-resistant weed control and soybean injury in response to different PPOinhibiting herbicides. J Agr Sci 8:1-9

Aulakh JS, Jhala AJ (2015) Comparison of glufosinate-based herbicide programs for broad-spectrum weed control in glufosinate-resistant soybean. Weed Technol 29:419-430

Beckie HJ (2011) Herbicide-resistant weed management: focus on glyphosate. Pest Manag Sci 67:1037-1048

Bensch CN, Horak MJ, Peterson D (2003) Interference of redroot pigweed (Amaranthus retroflexus), Palmer amaranth (A. palmeri), and common waterhemp (A. rudis) in soybean. Weed Sci 51:37-43

Burke IC, Schroeder M, Thomas WE, Wilcut JW (2007) Palmer amaranth interference and seed production in peanut. Weed Technol 21:367-371

Chahal PS, Jhala AJ (2015) Herbicide programs for control of glyphosate-resistant volunteer corn in glufosinate-resistant soybean. Weed Technol 29:431-443

Chandi A, Milla-Lewis SR, Giacomini D, Westra P, Preston C, Jordan DL, York AC, Burton JD, Whitaker JR (2012) Inheritance of evolved glyphosate resistance in a North Carolina Palmer amaranth (Amaranthus palmeri) biotype. Int J Agron 2012:1-7 doi: http://dx.doi.org/ 10.1155/2012/176108

Chatham LA, Bradley KW, Kruger GR, Martin JR, Owen MDK, Peterson DE, Mithila J, Tranel PJ (2015a) A multistate study of the association between glyphosate resistance and EPSPS gene amplification in waterhemp (Amaranthus tuberculatus). Weed Sci 63:569-577

Chatham LA, Wu C, Riggins CW, Hager AG, Young BG, Roskamp GK, Tranel PJ (2015b) EPSPS gene amplification is present in the majority of glyphosate-resistant Illinois waterhemp (Amaranthus tuberculatus) populations. Weed Technol 29:48-55

Corbett JL, Askew SD, Thomas WE, Wilcut JW (2004) Weed efficacy evaluations for bromoxynil, glufosinate, glyphosate, pyrithiobac, and sulfosate. Weed Technol 18:443-453

Craigmyle BD, Ellis JM, Bradley KW (2013) Influence of weed height and glufosinate plus 2,4-D combinations on weed control in soybean with resistance to 2,4-D. Weed Technol 27:271-280

Culpepper AS, Grey TL, Vencill WK, Kichler JM, Webster TM, Brown SM, York AC, Davis JW, Hanna WW (2006) Glyphosate resistant Palmer amaranth (Amaranthus palmeri) confirmed in Georgia. Weed Sci 54:620-626

Culpepper AS, Webster TM, Sosnoskie LM, York AC (2010) Glyphosate-resistant Palmer amaranth in the US. Pages 195-212 in Nandula VK, ed. Glyphosate Resistance: Evolution, Mechanisms, and Management. Hoboken, NJ: J Wiley 
Dinelli G, Marotti I, Bonetti A, Catizone P, Urbano JM, Barnes J (2008) Physiological and molecular bases of glyphosate resistance in Conyza bonariensis biotypes from Spain. Weed Res 48:257-265

Franssen AS, Skinner DZ, Al-Khatib K, Horak MJ, Kulakow PA (2001) Interspecific hybridization and gene flow of ALS resistance in Amaranthus species. Weed Sci 49:598-606

Gaines TA, Shaner DL, Ward SM, Leach JE, Preston C, Westra P (2011) Mechanism of resistance of evolved glyphosate-resistant Palmer amaranth (Amaranthus palmeri). J Agric Food Chem 59:5886-5889

Gaines TA, Zhang W, Wang D, Bukun B, Chisholm ST, Shaner DL, Nissen SJ, Patzoldt WL, Tranel PJ, Culpepper AS, Grey TL, Webster TM, Vencill WK, Sammons RD, Jiang JM, Preston C, Leach JE, Westra P (2010) Gene amplification confers glyphosate resistance in Amaranthus palmeri. Proc Natl Acad Sci USA 107:1029-1034

Ge X, d'Avignon DA, Ackerman JJH, Sammons RD (2010) Rapid vacuolar sequestration: the horseweed glyphosate resistance mechanism. Pest Manag Sci 66:345-348

Grichar WJ (1994) Spiny amaranth (Amaranthus spinosus L.) control in peanut (Arachis hypogaea L.) Weed Technol 8: 199-202

Grichar WJ (1997) Control of Palmer amaranth (Amaranthus palmeri) in peanut (Arachis hypogaea) with postemergence herbicides. Weed Technol 11:739-743

Godar AS, Varanasi VK, Nakka S, Prasad PV, Thompson CR, Mithila J (2015) Physiological and molecular mechanisms of differential sensitivity of Palmer amaranth (Amaranthus palmeri) to mesotrione at varying growth temperatures. PLoS One 10:0126731

Gossett BJ, Toler JE (1999) Differential control of Palmer amaranth (Amaranthus palmeri) and smooth pigweed (Amaranthus hybridus) by postemergence herbicides in soybean (Glycine max). Weed Technol 13:165-168

Heap I (2016a) International Survey of Herbicide-Resistant Weeds. http://www.weedscience.org/Summary/Species.aspx. Accessed May 15, 2016

Heap I (2016b). Weeds Resistant to ALS Inhibitors. http://www. weedscience.org/Summary/MOA.aspx. Accessed May 27, 2016

Herrmann KM, Weaver LM (1999) The shikimate pathway. Annu Rev Plant Physiol Plant Mol Biol 50:473-503

Horak MJ, Loughin TM (2000) Growth analysis of four Amaranthus species. Weed Sci 48:347-355

Horak MJ, Peterson DE (1995) Biotypes of Palmer amaranth (Amaranthus palmeri) and common waterhemp (Amaranthus rudis) are resistant to imazethapyr and thifensulfuron. Weed Technol 9:192-195

Jhala AJ, Sandell LD, Rana N, Kruger GR, Knezevic SZ (2014) Confirmation and control of triazine and 4-hydroxyphenylpyruvate dioxygenase-inhibiting herbicide-resistant Palmer amaranth (Amaranthus palmeri) in Nebraska. Weed Technol 28:28-38

Jugulam M, Niehues K, Godar AS, Koo DH, Danilova T, Friebe B, Sehgal S, Varanasi VK, Wiersma A, Westra P, Stahlman PW, Gill BS (2014) Tandem amplification of a chromosomal segment harboring 5-enolpyruvylshikimate3-phosphate synthase locus confers glyphosate resistance in Kochia scoparia. Plant Physiol 166:1200-1207
Kaundun SS, Dale RP, Zelaya IA, Dinelli G, Marotti I, McIndoe E, Cairns A (2011) A novel P106L mutation in EPSPS and an unknown mechanism(s) act additively to confer resistance to glyphosate in a South African Lolium rigidum population. J Agric Food Chem 59:3227-3233

Keeley PE, Carter CH, Thullen RJ (1987) Influence of planting date on growth of Palmer amaranth (Amaranthus palmeri). Weed Sci 35:199-204

Knezevic SZ, Streibig JC, Ritz C (2007) Utilizing R software package for dose-response studies: the concept and data analysis. Weed Technol 21:840-848

Liphadzi KB, Dille JA (2006) Annual weed competitiveness as affected by preemergence herbicide in corn. Weed Sci 54:156-165

Massinga RA, Currie RS, Horak MJ, Boyer J Jr (2001) Interference of Palmer amaranth in corn. Weed Sci 49:202-208

Merchant RM, Culpepper AS, Eure PM, Richburg JS, Braxton LB (2014) Controlling glyphosate-resistant Palmer amaranth (Amaranthus palmeri) in cotton with resistance to glyphosate, 2,4-d, and glufosinate. Weed Technol 28:291-297

Mohseni-Moghadam M, Schroeder J, Ashigh J (2013a) Mechanism of resistance and inheritance in glyphosate resistant Palmer amaranth (Amaranthus palmeri) populations from New Mexico, USA. Weed Sci 61:517-525

Mohseni-Moghadam M, Schroeder J, Heerema R, Ashigh J (2013b) Resistance to glyphosate in Palmer amaranth (Amaranthus palmeri) populations from New Mexico pecan orchards. Weed Technol 27:85-91

Nandula VK, Reddy KN, Kroger CH, Poston DH, Rimando AM, Duke SO, Bond JA, Ribeiro DN (2012) Multiple resistance to glyphosate and pyrithiobac in Palmer amaranth (Amaranthus palmeri) from Mississippi and response to flumiclorac. Weed Sci 60:179-188

Nandula VK, Wright AA, Bond JA, Ray JD, Eubank TW, Molin WT (2014) EPSPS amplification in glyphosate-resistant spiny amaranth (Amaranthus spinosus): a case of gene transfer via interspecific hybridization from glyphosate-resistant Palmer amaranth (Amaranthus palmeri). Pest Manag Sci 70:1902-1909

Norsworthy JK, Griffith GM, Scott RC, Smith KL, Oliver LR (2008) Confirmation and control of glyphosate-resistant Palmer amaranth (Amaranthus palmeri) in Arkansas. Weed Technol 22:108-113

Perez-Jones A, Park KW, Polge N, Colquhoun J, Mallory-Smith CA (2007) Investigating the mechanisms of glyphosate resistance in Lolium multiflorum. Planta 226:395-404

Pfaffl MW (2001) A new mathematical model for relative quantification in real-time RT-PCR. Nucl Acids Res 29:2002-2007

Powles SB, Lorraine-Colwill DF, Dellow JJ, Preston C (1998) Evolved resistance to glyphosate in rigid ryegrass (Lolium rigidum) in Australia. Weed Sci 46:604-607

Reddy SS, Stahlman PW, Geier PW, Bean BW, Dozier T (2014) Grain sorghum response and Palmer amaranth control with postemergence application of fluthiacet-methyl. Int J Pest Manag 60:147-152

Ribeiro DN, Pan Z, Duke SO, Nandula VK, Baldwin BS, Shaw DR, Dayan FE (2014) Involvement of facultative apomixis in inheritance of EPSPS gene amplification in glyphosate-resistant Amaranthus palmeri. Planta 239:199-212. doi: 10.1007/ s00425-013-1972-3 
Salas RA, Burgos NR, Tranel PJ, Singh S, Glasgow L, Scott RC, Nichols RL (2016) Resistance to PPO-inhibiting herbicide in Palmer amaranth from Arkansas. Pest Manag Sci 72:864-869

Sarangi D (2016) Biology, Gene Flow, and Management of Glyphosate-Resistant Common Waterhemp (Amaranthus rudis Sauer) in Nebraska. Ph.D dissertation. Lincoln, NE: University of Nebraska-Lincoln. $94 \mathrm{p}$

Sarangi D, Sandell LD, Knezevic SZ, Aulakh JS, Lindquist JL, Irmak S, Jhala AJ (2015) Confirmation and control of glyphosate-resistant common waterhemp (Amaranthus rudis) in Nebraska. Weed Technol 29:82-92

Sauer JD (1957) Recent migration and evolution of the dioecious amaranths. Evolution 11:11-31

Simarmata M, Penner D (2008) The basis for glyphosate resistance in rigid ryegrass (Lolium rigidum) from California. Weed Sci 56:181-188

Smith DT, Baker RV, Steele GL (2000) Palmer amaranth (Amaranthus palmeri) impacts on yield, harvesting, and ginning in dryland cotton (Gossypium hirsutum). Weed Technol 14:122-126

Steckel LE (2007) The dioecious Amaranthus spp.: here to stay. Weed Technol 21:567-570

Steckel LE, Main CL, Ellis AT, Mueller TC (2008) Palmer amaranth (Amaranthus palmeri) in Tennessee has low level glyphosate resistance. Weed Technol 22:119-123

Steinrücken HC, Amrhein N (1980) The herbicide glyphosate is a potent inhibitor of 5-enolpyruvyl-shikimic acid-3-phosphate synthase. Biochem Biophys Res Commun 94:1207-1212

Sweat JK, Horak MJ, Peterson DE, Lloyd RW, Boyer JE (1998) Herbicide efficacy on four Amaranthus species in soybean (Glycine max). Weed Technol 12:315-321

[USGS] United States Geological Survey (2016) Estimated agricultural use for glyphosate, 1992-2013. http://water.usgs.gov/nawqa/ pnsp/usage/maps/show_map.php?year=1996\&map=GLYPHOSA TE\&hilo=L. Accessed May 24, 2016

VanGessel MJ (2001) Glyphosate-resistant horseweed from Delaware. Weed Sci 49:703-705

Varanasi VK, Betha S, Thompson CR, Jugulam M (2015). Target and non-target site multiple herbicide resistance in
Palmer amaranth (Amaranthus palmeri) from Kansas. Page 81 in Proceedings of the 70th North Central Weed Science Society. Indianapolis, IN: North Central Weed Science Society

Wakelin AM, Lorraine-Colwill DF, Preston C (2004) Glyphosate resistance in four different populations of Lolium rigidum is associated with reduced translocation of glyphosate to meristematic zones. Weed Res 44:453-459

[WSSA] Weed Science Society of America (2016) WSSA Survey Ranks Palmer Amaranth as the Most Troublesome Weed in the U.S., Galium as the Most Troublesome in Canada. http://wssa. net/2016/04/wssa-survey-ranks-palmer-amaranth-as-the-mosttroublesome-weed-in-the-u-s-galium-as-the-most-troublesome-incanada/. Accessed May 22, 2016

Whitaker JR, Burton JD, York AC, Jordan DL, Chandi A (2013) Physiology of glyphosate-resistant and glyphosate-susceptible Palmer amaranth (Amaranthus palmeri) biotypes collected from North Carolina. Int J Agron 2013:1-6. doi: http://dx.doi.org/ $10.1155 / 2013 / 429294$

Wiersma AT, Gaines TA, Preston C, Hamilton JP, Giacomini D, Robin Buell C, Leach JE, Westra P (2015) Gene amplification of 5-enol-pyruvylshikimate-3-phosphate synthase in glyphosateresistant Kochia scoparia. Planta 241:463-474

Woodburn AT (2000) Glyphosate: production, pricing and use worldwide. Pest Manag Sci 56:309-312

Wortman SE (2014) Integrating weed and vegetable crop management with multifunctional air-propelled abrasive grits. Weed Technol 28:243-252

Yu Q, Cairns A, Powles S (2007) Glyphosate, paraquat and ACCase multiple herbicide resistance evolved in a Lolium rigidum biotype. Planta 225:499-513

Received July 22, 2016, and approved September 9, 2016.

Associate Editor for this paper: Prashant Jha, Montana State University. 